\title{
SLOVÁCI V ČESKÉ REPUBLICE: S DU゚RAZEM NA DOJÍŽD̆KU ZA PRACÍ A DO VYSOKÝCH ŠKOL
}

\section{SLOVAKS IN THE CZECH REPUBLIC: WITH EMPHASIS ON COMMUTING TO WORK AND UNIVERSITIES}

\author{
RNDR. ONDŘEJ ŠERÝ ${ }^{1}$ \\ RNDr. Tatiana MiNTÁlová, Ph.D. ${ }^{2}$ \\ DOC. RNDR. ZDENĚK SZCZYRBA, PH.D. ${ }^{2}$ \\ DOC. RNDR. VÁCLAV TOUŠEK, CSC. ${ }^{2}$ \\ ${ }^{1}$ Geografický ústav ${ }^{1}$ Department of Geography \\ Prírodovédecká fakulta Faculty of Science \\ Masarykova univerzita Masaryk University \\ $\triangle$ Kotlářská 2, 61137 Brno, Czech Republic \\ E-mail: ondrej.sery@mail.muni.cz \\ ${ }^{2}$ Katedra geografie ${ }^{2}$ Department of Geography \\ Prírodovédecká fakulta Faculty of Science \\ Univerzita Palackého v Olomouci Palacký University in Olomouc \\ $\triangle$ 17. listopadu 12, 77146 Olomouc, Czech Republic \\ E-mail:tatiana.mintalova@upol.cz,zdenek.szczyrba@upol.cz,vaclav.tousek@upol.cz
}

\begin{abstract}
Anotace
Př́spěvek obsahuje regionálně geografickou analýzu zmèn v dojižd'ce za prací a do vysokých škol ze Slovenska do České republiky a opačným směrem vobdobi po rozděleni Československa na konci roku 1992. Zatímco po rozdèleni společného státu frekvence cest občanů ČR na Slovensko výraznè poklesla a k nijak vysokému náruistu nedošlo ani po přistoupeni obou nástupnických zemí do EU $v$ roce 2004, totéž nelze konstatovat v prípadě cest občanů Slovenska do ČR. Četnost nékterých kontaktů ve směru SR - ČR se naopak postupně zvyšuje. Počet občanů Slovenska dojiždějicich za prací do ČR se zvýšil od konce roku 1992 téměř šestinásobně a počet vysokoškoláku studujicich v ČR je zhruba desetinásobný. Př́spěvek se mimo jiné zabývá přičinami tohoto vývoje.

\section{Klič́ová slova}

česko-slovenské kontakty, dojižd'ka za praci, dojižd’ka do vysokých škol

\section{Annotation}

The paper includes a regional geographical analysis of the changes in commuting to work and universities from Slovakia to the Czech Republic and in the opposite direction after the split of Czechoslovakia at the end of 1992. The frequencies of travel by Czech citizens to Slovakia significantly decreased and there was no considerable increase after both states joined the EU in 2004; the same cannot be said of travel to the Czech Republic by Slovak citizens. On the contrary, the frequency of some contacts in the direction of the Slovak Republic - Czech Republic is gradually increasing. Number of commuters to work from Slovakia to the Czech Republic has increased almost six times since the end of 1992 and the number of university students studying in the Czech Republic is roughly tenfold. The paper among other things deals with the causes of this development.
\end{abstract}




\author{
Key words \\ Czech-Slovak contacts, labour commuting, university commuting
}

JEL classification: $I 21, J 61$

\title{
1. Úvod
}

Na přelomu let 1992 a 1993 došlo k rozdělení československé federace na dva nástupnické státy Českou republiku a Slovenskou republiku. I přes tuto událost však zůstaly vzájemné vazby na nadstandardní úrovni. Umožňovaly to některé mezivládní smlouvy, které vstoupily v platnost ihned od ledna 1993. K zachování vysoké intenzity vztahů stejně jako ke snížení vlivu hraničního efektu pak výrazně přispěly společný vstup do EU v roce 2004 a začlenění do Schengenského prostoru o tři roky později.

Vlivem hranice, tj. hraničním efektem, se zabývali Jeřábek, Dokoupil, Havlíček et al. (2004), kteří uvedli, že síla a charakter tohoto efektu závisí především na typu a funkci hranice. V př́ípadě uzavřené hranice roste význam bariérového hraničního efektu, což znamená jednostrannou orientaci př́hraničního regionu na vnitrozemí a posílení perifernosti. Naopak otevřená hranice přináší kontaktní hraniční efekt, jenž představuje rozvoj vztahů přes hranice a oslabení perifernosti. Uzavřenost nebo otevřenost hranice předznamenává filtrační hraniční efekt, který usměrňuje procesy procházející hraničními přechody. Pokud je hranice méně propustná, nastává koncentrační hraniční efekt soustředící procesy pouze do vybraných směrů.

Míra a především polarita přeshraničních vztahů jsou podle Dokoupila (2002) odvislé od ekonomické úrovně sousedních regionů (států). Pokud je vyspělost srovnatelná, jedná se o symetrickou hranici. Za této situace jsou základem oboustranně orientovaných přeshraničních vztahů rozšíření a doplnění sortimentu zboží či služeb v sousedních regionech a poznání př́rodního či kulturního potenciálu sousedního regionu s cílem udržovat dobré sousedství na bázi zdravé konkurence. V př́ípadě, že je však ekonomická vyspělost regionů rozdílná, označuje se hranice jako asymetrická. Přeshraniční vztahy pak mají rozdílný charakter. Jejich základem je profitování z ekonomické nerovnováhy.

Ekonomickým vazbám mezi Českou republikou a Slovenskem se věnovali Halás a Kladivo (2008), kteří analyzovali vzájemný zahraniční obchod a pracovní a studijní migrace. Podle nich Slováci v České republice obsazují především méně atraktivní pracovní pozice, o něž nemá domácí obyvatelstvo zájem (i když toto se postupně mění a stále více se uplatňují také kvalifikovaní pracovníci). V prŕípadě slovenských studentů konstatují, že největší zájem je o mezinárodně nejuznávanější univerzity a některé moravské univerzity, kde hraje silnou roli vzdálenost. Pracovní a studijní migrace ze Slovenska do ČR byly předmětem kvalifikační práce Slotíkové (2013) z Katedry geografie Př́rodovědecké fakulty Univerzity Palackého v Olomouci.

Působením občanů Slovenska v ČR a naopak se zabývalo i několik vědecko-výzkumných projektů řešených Geografickým ústavem Přírodovědecké fakulty Masarykovy univerzity. Konkrétně se jednalo o projekty Grantové agentury ČR „Aktuální změny prostorových interakcí na moravsko-slovenském pomezi“, „Postavení pohraničí v regionálním rozvoji České republiky se zřetelem k zapojení ČR do evropských struktur“ a „Pracovně podmíněné migrace jako součást mezinárodního (přeshraničního) trhu práce Česka v kontextu evropské integrace“. Výsledky výzkumu publikovali Řehák a Daněk (1997) či Řehák (1998), kteří označují česko-slovenskou hranici jako pulzující hranici, tj. při relativní stabilitě území se vždy měnila jen míra její otevřenosti. Dále je možné uvést práce Touška (1999) či Touška a Tomšíčkové (2000) zaměřující se na soudobé tendence v zaměstnávání občanů Slovenska v ČR a na obousměrnou dojížd’ku za službami (především za nákupy). Problematikou česko-slovenských vztahů se Geografický ústav zabýval i v dalších letech. Posledním publikovaným př́spěvkem byla studie Šerého, Hercika a Touška (2012) věnovaná otázce působení občanů Slovenska v ČR v období téměř dvaceti let po rozdělení ČSFR. Na slovenské straně realizovali výzkumy týkající se problematiky regionálních aspektů slovensko-českých vztahů 
především geografové z Přírodovědecké fakulty Univerzity Komenského v Bratislavě. Značná část výsledků byla prezentována v monografii Haláse (2005).

Následující text rozšiřuje poznatky studované problematiky o aktuální údaje týkající se dojížd’ky za prací z jednoho státu do druhého a dojížd'ky do vysokých škol. Cílem př́spěvku tak je poukázat na působení (vliv) Slováků v České republice v posledních dvaceti letech.

\section{Dojîž̌d'ka do zaměstnání (pracovní migrace)}

Zaměstnávání občanů Slovenska má v Čechách a na Moravě dlouholetou tradici. V dobách existence společného státu, a to především v 50. a 60 . letech 20 . století, hledal pracovní uplatnění v ČR poměrně značný počet osob bydlících na Slovensku. S rozvojem slovenského hospodářství podpořeným značnými investicemi do průmyslové infrastruktury se tento počet trvale snižoval (viz tab. 1). Vzhledem ke značné vzdálenosti mezi místem bydliště a místem pracoviště se často nejednalo o denní dojížd'ku (tzv. pendlerství). Tuto formu prostorové mobility šlo ve zvýšené míře sledovat pouze v př́ihraničí. Převážná část tak připadala na nedenní dojížd’ku do zaměstnání. V této kapitole jsou tedy za pracující Slováky v ČR označovány osoby vykazující jak denní, tak nedenní dojížd’ku, ale vždy $\mathrm{s}$ trvalým bydlištěm na území Slovenska.

Tab. 1: Vývoj dojižd'ky za prací mezi ČR a SR v letech 1961-1991 (v tis. osob)

\begin{tabular}{|l|r|r|r|r|}
\hline & 1961 & \multicolumn{1}{|c|}{1970} & \multicolumn{1}{c|}{1980} & 1991 \\
\hline vyjižž́jící ze SR do ČR & 88,2 & 48,5 & 40,4 & 30,0 \\
\hline vyjižž́jící z ČR do SR & 6,2 & 5,3 & 6,4 & 5,2 \\
\hline dojiźż'kové saldo & 82,0 & 43,2 & 34,0 & 24,8 \\
\hline
\end{tabular}

V roce 1991 bylo nejvíce pracujících, kteří dojížděli ze Slovenska, zaměstnáno v hlavním městě Praze, a to 6,8 tis. osob. Jednalo se především o pracovníky ve stavebnictví a zaměstnance ústředních orgánů státní a veřejné správy. Nejsilnější koncentrace dojíždějících za prací ze SR však byla v ostravské aglomeraci, př́imo v Ostravě se jednalo o 4,4 tis. osob, v okrese Karviná o 3,3 tis. osob a v okrese Frýdek-Místek 2,9 tis. osob. Občané SR zde byli zaměstnaní především v podnicích černé metalurgie a těžby černého uhlí. V šesti okresech moravsko-slovenského pomezí (Břeclav, Hodonín, Uherské Hradiště, Zlín, Vsetín, Frýdek-Místek) bylo zaměstnáno 5,9 tis. občanů SR, tj. 19,6 \% ze všech dojíždějících ze SR. Naopak vyjížd'ka z ČR do SR byla mnohem méně četná (5,2 tis. osob). Z okresů moravsko-slovenského pomezí vyjíždělo za prací na Slovensko 2018 osob, tj. 38,8 \% ze všech vyjíždějících za prací na Slovensko.

Po rozdělení ČSFR bylo snahou upravit otázky zaměstnávání občanů SR v ČR a naopak takovým způsobem, aby se vazby mezi nově vzniklými státy narušily co nejméně. $Z$ tohoto důvodu byla mezi ČR a Slovenskem uzavřena na konci roku 1992 Smlouva o vzájemném zaměstnávání občanů obou republik. Zaměstnávání na základě Smlouvy nevyžadovalo pro občany SR ani ČR povolení k zaměstnání, jako tomu bylo u ostatních cizinců. Od vstupu obou zemí do EU v roce 2004 není toto povolení potřebné ani pro prř́slušníky ostatních států EU a také občany Islandu, Lichtenštejnska, Norska a Śvýcarska.

Nárůst počtu dojíždějících ze Slovenska do ČR po rozdělení státu reprezentuje obr. 1 . V době rozdělení ČSFR pracovalo na českém území 23,4 tis. občanů SR. Vzhledem k vysoké míře nezaměstnanosti na Slovensku v první polovině 90 . let došlo v ČR k nárůstu počtu zahraničních pracovníků ze Slovenska. Jejich počet se přiblížil hranici 80 tis. V období recese české ekonomiky na konci 90. let byla část pracovníků ze Slovenska uvolněna, takže jejich počet na konci roku 1999 činil necelých 60. tis. Opětovný nárůst dojíždějících za prací ze Slovenska je patrný od roku 2002. Na konci roku 2006 se počet občanů SR pracujících v Č́R přiblížil hranici 100 tis. V období let 2007 až 2010 se jejich počet ustálil na hranici 110 tis. Tento stav významně nezměnila ani globální 
ekonomická krize. Zatím největší počet slovenských občanů byl registrován na konci roku 2011, kdy na trhu práce v ČR působilo 117,8 tis. občanů SR (2,1 \% pracovní síly ČR).

\section{Obr. 1: Občané SR pracujícív České republice v letech 1993 až 2011 (vždy k 31. 12.)}

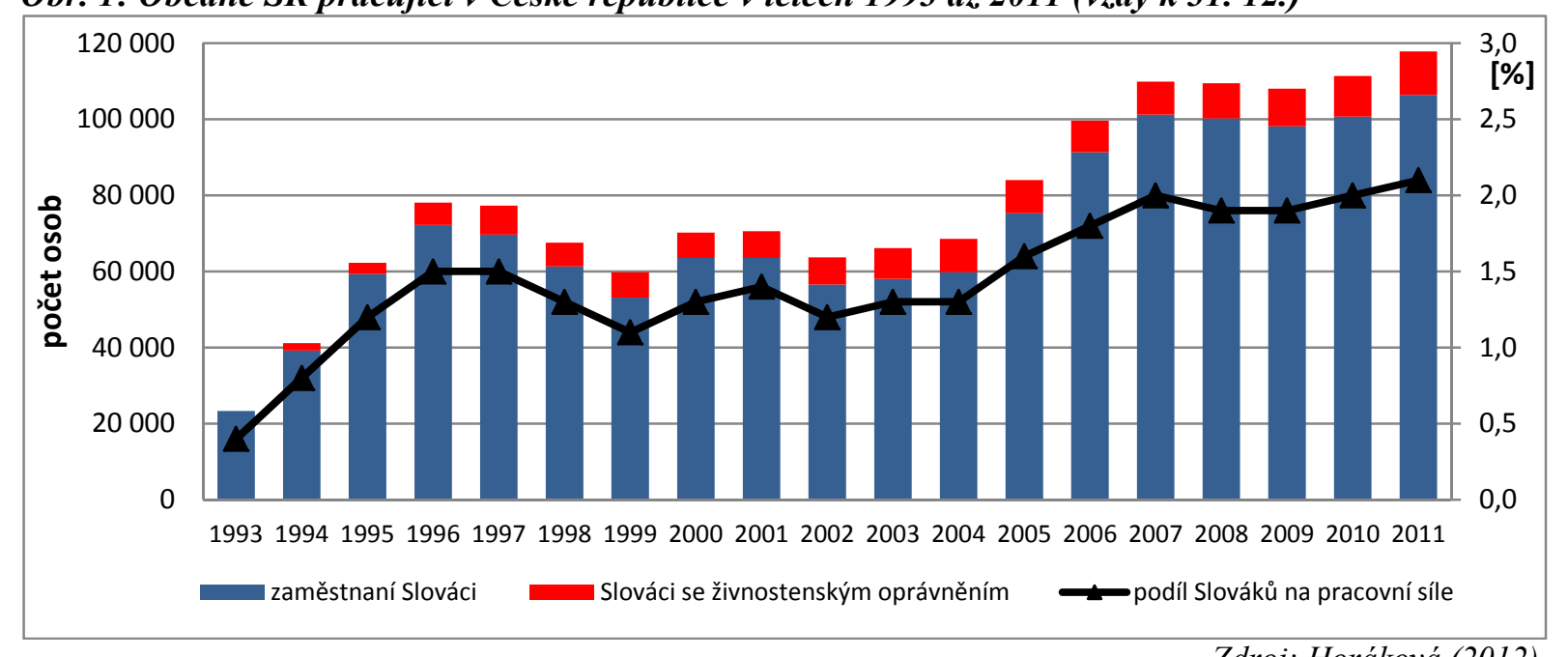

Zdroj: Horáková (2012)

Na konci roku 2000 byl největší podíl slovenských občanů na pracovní síle ČR zjištěn v okresech Hodonín (3,2 \%), Mladá Boleslav (3,0\%), Vsetín (2,9\%), Ostrava-město (2,8\%), Ústí nad Orlicí $(2,7 \%)$ a hlavním městě Praze $(2,5 \%)$. Vysoký podíl v př́ípadě okresu Mladá Boleslav byl způsoben zaměstnáváním Slováků ve společnosti Škoda Auto, v př́ípadě okresu Ústí nad Orlicí pak v elektrotechnické firmě AVX Czech Republic v Lanškrouně. Pro zaměstnávání občanů SR byla atraktivní především velká města. Největší počet pracujících Slováků vykazovala Praha (16,2 tis.), Brno (4,9 tis.) a Ostrava (4,4 tis.). Význam okresů moravsko-slovenského pomezí (zejména jeho severní části), kde bylo zaměstnáno 9979 občanů SR (tj. 15,7\% všech Slováků pracujících v ČR), se snižoval. Tento trend pokračoval i v následujícím desetiletí.

Tab. 2: Deset okresů ČR s nejvyšším a deset okresů ČR s nejnižším počtem občanů SR registrovaných $\mathrm{k} 31.12 .2011$ na Úradu práce $\check{C} R$

\begin{tabular}{|c|l|r|r|r|l|r|r|}
\hline Pořadí & \multicolumn{1}{|c|}{ Okres } & $\begin{array}{c}\text { počet } \\
\text { občanů } \\
\text { SR }\end{array}$ & $\begin{array}{c}\text { podíl na } \\
\text { pracovní } \\
\text { síle }(\%)\end{array}$ & Pořadí & Okres & $\begin{array}{c}\text { počet } \\
\text { občanů } \\
\text { SR }\end{array}$ & $\begin{array}{c}\text { podíl na } \\
\text { pracovní } \\
\text { síle (\%) }\end{array}$ \\
\hline 1. & Praha & 37326 & 4,8 & 68. & Prachatice & 201 & 0,7 \\
\hline 2. & Brno-město & 8344 & 3,8 & 69. & Znojmo & 199 & 0,3 \\
\hline 3. & Plzeň-město & 5030 & 4,5 & 70. & Rakovník & 191 & 0,6 \\
\hline 4. & Mladá Boleslav & 4469 & 6,0 & 71. & Kroměříž & 185 & 0,3 \\
\hline 5. & Praha-východ & 4400 & 5,2 & 72. & Sokolov & 169 & 0,3 \\
\hline 6. & Ostrava-město & 3290 & 1,9 & 73. & Třebíć & 148 & 0,2 \\
\hline 7. & Frýdek-Místek & 2179 & 2,0 & 74. & Jindřichův Hradec & 146 & 0,3 \\
\hline 8. & Pardubice & 2092 & 2,3 & 75. & Bruntál & 135 & 0,3 \\
\hline 9. & Zlín & 1661 & 1,6 & 76. & Děč́n & 69 & 0,1 \\
\hline 10. & Liberec & 1595 & 1,7 & 77. & Jeseník & 38 & 0,2 \\
\hline
\end{tabular}

Na konci roku 2011 byl největší podíl občanů SR na pracovní síle zaznamenán v okresech Mladá Boleslav $(6,0 \%)$, Praha-východ (5,2 \%), hlavní město Praha $(4,8 \%)$ a Plzeň-město $(4,5 \%)$ s patrným vlivem výrobce televizoru Panasonic AVC Networks Czech. V Praze působila téměř třetina všech občanů SR registrovaných na úřadech práce $(37,3$ tis.). Co se týká počtu pracujících Slováků, následovala za Prahou města Brno ( 8,3 tis.) a Plzeň $(5,0$ tis.). V moravsko-slovenském pomezí počet pracujících Slováků během deseti let dále klesal, a to o 1,5 tis. na 8487 osob (tj. pouze $8,0 \%$ ze všech občanů SR vedených na Úřadě práce ČR). 


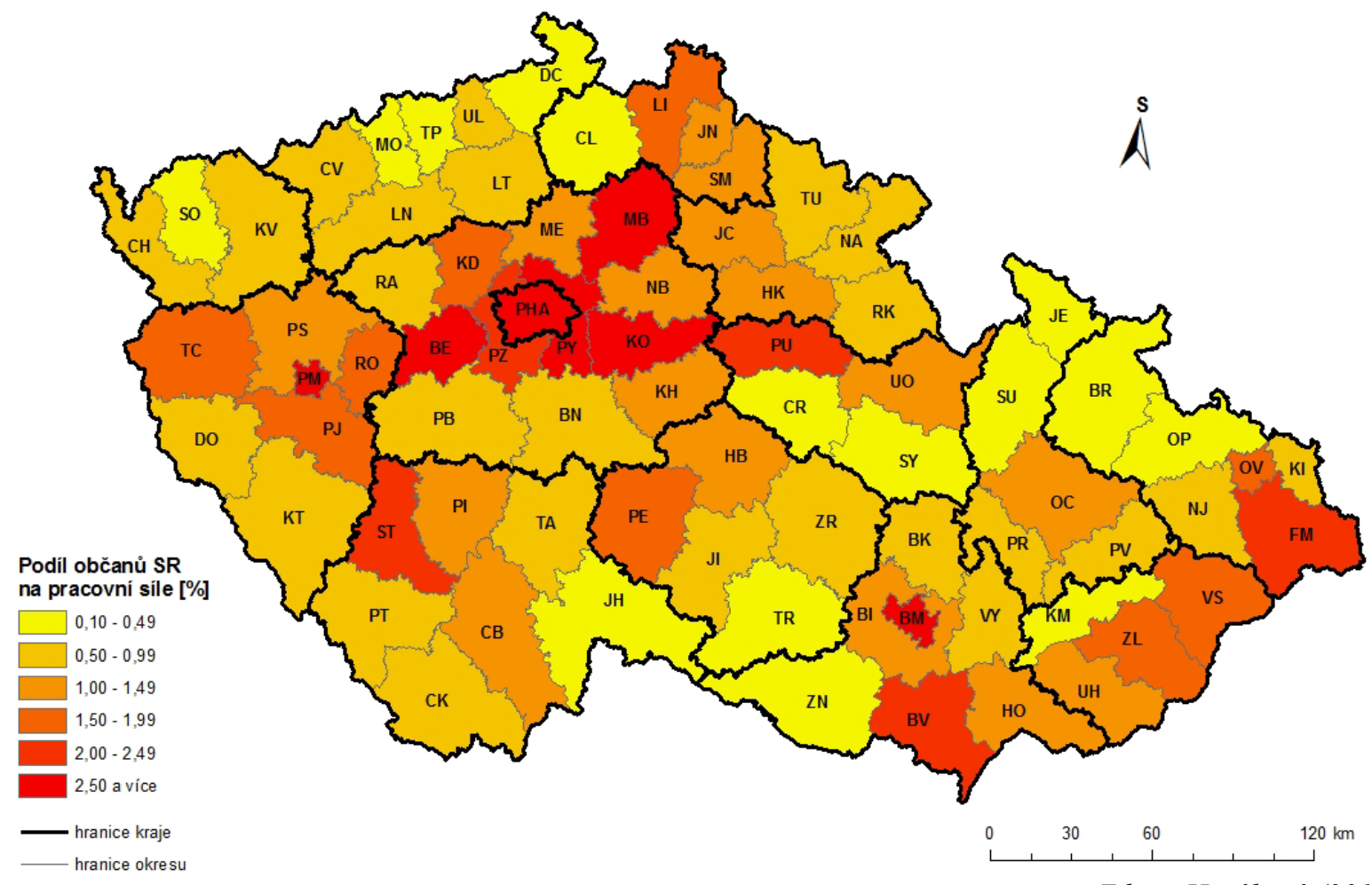

Zdroj: Horáková (2012)

Regionálně-geografické analýzy se zaměřují spíše na problematiku působení občanů SR na českém trhu práce, avšak málo pozornosti je věnováno práci občanů ČR na Slovensku. Je to dáno skutečností, že nejen počet občanů ČR, ale také všech cizinců, pracujících v Slovenské republice není nijak vysoký. V posledních letech se však situace mění, a to v souvislosti s vytvářením nových pracovních míst $\mathrm{v}$ průmyslových společnostech se zahraniční kapitálovou účastí. Na konci roku 2008 pracovalo na Slovensku necelých 14 tis. cizinců, o 3 roky později jejich počet dosahoval 22,2 tis. (v ČR šlo v tom okamžiku o 310 tis. cizinců). Více než třetina (7,7 tis.) jich pracovala v Bratislavě a dále existovaly již pouze 2 okresy, ve kterých bylo zaměstnáno více než 1 tis. cizinců. Jednalo se o Trnavu (1,9 tis.), kde cizinci pracovali zejména v automobilce PSA Peugeot Citroën Slovakia a o Galantu (1,2 tis.) - práce ve firmě Samsung Electronics Slovakia zaměřené zejména na výrobu LCD a LED televizorů. Počtem zaměstnaných na slovenském trhu práce je ČR v posledních letech na druhém místě po Rumunsku. Na konci roku 2011 bylo v SR zaměstnáno 4,5 tis. občanů Rumunska, 3,2 tis. občanů ČR a po 2,2 tis. občanů Polska a Mad'arska.

V letech 1991 a 1992 se počet občanů ČR dojíždějících za prací na Slovensko snížil na necelých 4 tis., po rozdělení společného státu šlo o pokles až pod hranici 1 tis. Poté sice došlo k mírnému nárůstu, ale počet dojíždějicích za prací na Slovensko se dlouhodobě udržoval pod hranicí 2 tis. a tato byla prolomena během roku 2009. Více než 60 \% občanů ČR dojíždělo za prací do Bratislavy. Za jediný významnější dojížd'kový proud v moravsko-slovenském pomezí ve směru ČR - SR šlo považovat dojižd'ku občanů obce Sudoměřice do Skalice, kde je dosud jejich největším zaměstnavatelem průmyslová firma INA SKALICA zaměřující se na výrobu ložisek.

Kde hledat př́ičiny tzv. asymetrické hranice v př́padě pracovní migrace mezi ČR a SR. Rozdíly vekonomické vyspělosti obou zemí ve prospěch ČR nejsou až tak výrazné. Slovensko patř́ v posledních letech mezi nejrychleji rostoucí ekonomiky zemí EU. Jeho hrubý domácí produkt dosáhl v paritě kupní síly již $77 \%$ průměru EU (v případě ČR jde o $80 \%$ ). Rozdíly v průměrné nominální měsíční mzdě zaměstnanců činí asi $20 \%$, nebot' tato v roce 2011 dosahovala na Slovensku 786 euro a v ČR 942 euro. Hlavní př́ičinou daleko většího počtu pracujících Slováků v České republice jsou 
poměrně velké rozdíly v situaci na trhu v obou zemích. Harmonizovaná míra nezaměstnanosti zjištěna výběrovým šetřením pracovních sil je na Slovensku dvojnásobná oproti ČR. V roce 2011 dosahovala v SR hodnoty $13,6 \%$, zatímco v ČR pouze $6,7 \%$. I když rozdíly v míře registrované nezaměstnanosti jsou o něco menší, situace na trhu práce zvláště ve východní polovině Slovenska je špatná. V krajích Banskobystrickém, Prešovském i Košickém kraji je nezaměstnána každá pátá ekonomicky aktivní osoba. V některých okresech (např. Rimavská Sobota, Revúca) míra registrované nezaměstnanosti překračuje hranici $30 \%$. Nedostatek nových pracovních míst umocňován neexistencí jazykové bariéry je přičinou hledání pracovního uplatnění v sousední České republice.

\section{Dojížd'ka do vysokých škol}

Rozdíly mezi počtem dojíždějících studentů do vysokých škol ze Slovenska do českých zemí a z území dnešní ČR do SR za existence společného státu, zejména v období po 2. světové válce, nebyly $\mathrm{až} \mathrm{tak} \mathrm{velké} \mathrm{jako} \mathrm{v}$ př́padě pracovní migrace. Napomohly tomu také některé delimitace vysokoškolských pracovišt' z Čech a Moravy na Slovensko. Jednalo se především o přestěhování Vysoké školy dopravní v Praze do Žiliny v letech 1960 - 1962, dále o přemístění Farmaceutické fakulty Masarykovy univerzity do Bratislavy (byla sloučena s Farmaceutickou fakultou Univerzity Komenského) v roce 1960 a Vojenské politické akademie Klementa Gottwalda z Prahy do Bratislavy $\mathrm{v}$ roce 1969.

V akademickém roce 1992/1993 studovalo na vysokých školách v České republice dle odhadu Ministerstva školství, mládeže a tělovýchovy více než 2,5 tis. studentů ze Slovenska a jejich podíl na celkovém počtu vysokoškoláků v ČR dosahoval $2,2 \%$. Nejvíce studentů působilo na školách a fakultách s obory, které na Slovensku nebyly vyučovány. Na prvním místě je potřeba jmenovat Vojenskou akademii Antonína Zápotockého, teprve za ní se počtem slovenských studenti̊ řadily Masarykova univerzita a Univerzita Karlova. $Z$ fakult, ani tak počtem studentů, ale podílem studentů bydlících na Slovensku ze všech studentů fakulty vynikala Zahradnická fakulta v Lednici, která byla součástí tehdejší Vysoké školy zemědělské v Brně (dnešní Mendelova univerzita). Samostatná fakulta v Lednici byla zř́zena v roce 1985 a nabízela studium v oborech jako je zahradnictví, vinařství a krajinářská architektura, tedy oborech, které na Slovensku neexistovaly.

Počet studentů $s$ trvalým bydlištěm na území ČR studujících na slovenských školách dosahoval na počátku devadesátých let 1 tis. Zhruba polovina z nich dojižděla do Žiliny na Vysokou školu dopravy a spojů, která byla tvořena dvěma fakultami, a to Fakultou provozu a ekonomiky dopravy a Fakultou strojírenskou a elektrotechnickou. První fakulta měla celostátní (československou) působnost a vychovávala odborníky uplatňující se především v železniční, ale také i v silniční a letecké dopravě na území celé ČSFR. Vyšší koncentrací českých a moravských studentů vynikaly vojenské školy, at' už se jednalo o zmiňovanou Vojenskou politickou akademii KG nebo Vysokou vojenskou leteckou školu v Košicích, která byla zř́zena v roce 1972. Z nevojenských škol mezi školy či fakulty s významným zastoupením studentů bydlících v ČR patřily Vysoká škola ekonomická v Bratislavě a Farmaceutická fakulta UK. Jednalo se především o vysokoškoláky bydlící na jižní Moravě, pro které byla Bratislava časově dostupnějšśi, než např. Praha, nebo Hradec Králové v př́ípadě farmacie. Počet studentů ekonomických oborů $\mathrm{s}$ bydlišstěm $\mathrm{v}$ ČR na VŠE $\mathrm{v}$ Bratislavě však na počátku devadesátých let byl nižší než např. v letech sedmdesátých. Tato skutečnost byla ovlivněna zahájením výuky ekonomických oborů na nově vytvořené Ekonomické fakultě Vysoké školy báňské v Ostravě v roce 1977. 


\section{Obr. 3: Občané SR studující na vysokých školách v ČR ve všech formách výuky}

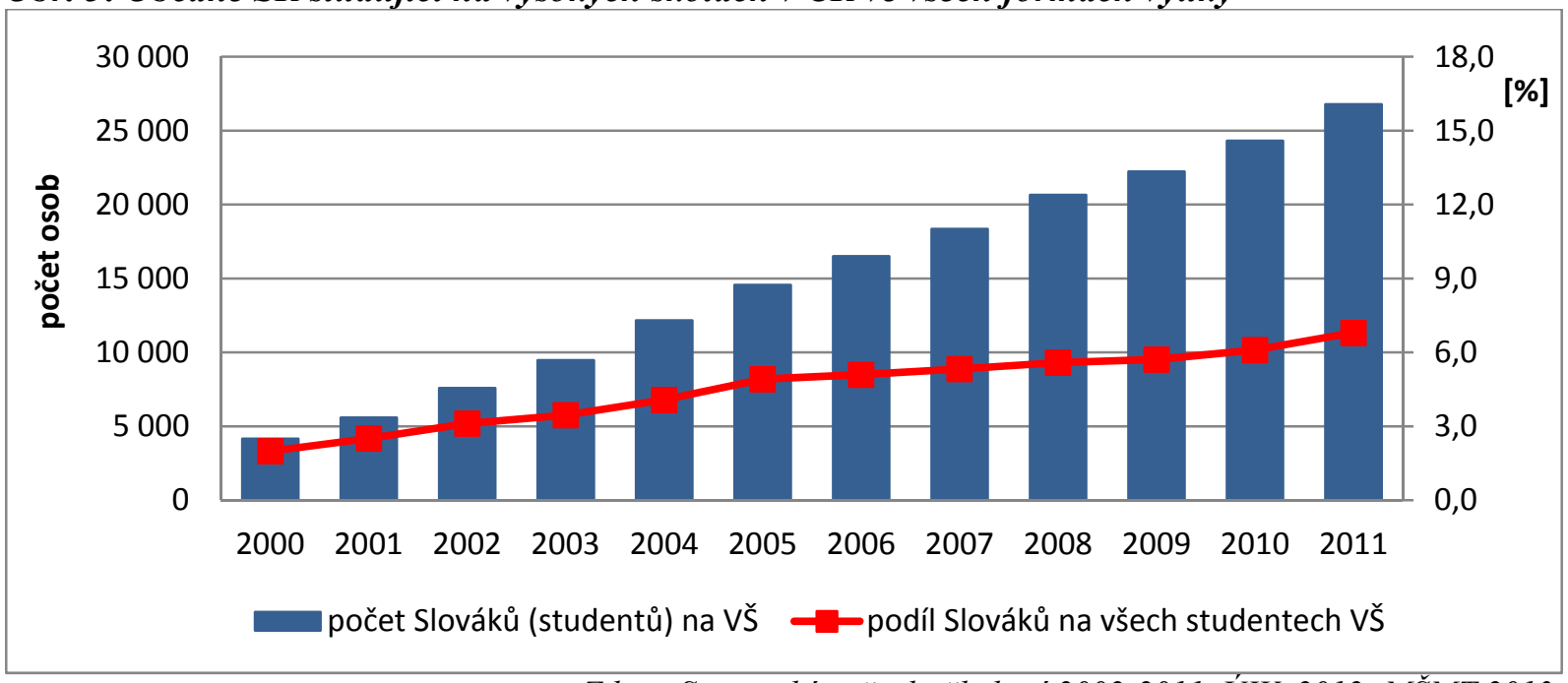

Zdroj: Statistické ročenky školství 2002-2011, ÚIV, 2012; MŠMT 2013

Po rozdělení společného státu se snížil na poměrně krátké období počet vysokoškolských studentů bydlících na Slovensku studujících v ČR, ale již v druhé polovině devadesátých let obliba některých českých vysokých škol u slovenských maturantů narůstá. To se projevuje i v počtu studentů se slovenskou státní př́slušností na vysokých školách v ČR. V akademickém roce 2000/2001 počet občanů SR studujících na českých vysokých školách překračuje hranici 4 tis. a o rok později hranici 5 tis. (viz obr. 3). Mezi akademickými roky 2001/2002 a 2011/2012 vzrostl počet Slováků více než pětinásobně. Jejich nárůst je velmi silně ovlivněn skutečností, že čeština a slovenština jsou podobné jazyky, takže studují na veřejných vysokých školách v programech s českým vyučovacím jazykem (tj. zdarma). Kromě veřejných škol na nárůstu počtu slovenských studentů participují také soukromé vysoké školy, jejichž vznik byl umožněn zákonem z roku 1999. Na veřejných vysokých školách v akademickém roce 2011/2012 působilo ve všech formách výuky19 956 studentů ze Slovenska a na soukromých vysokých školách pak dalších 6827 studentů (celkem 26783 ). Jejich podíl se tak na celkovém počtu studentů vysokých škol v ČR se tak zvýšil během deseti let z 2,5\% na 6,8 \%.

Tab. 3: Veřejné vysoké školy s největším počtem studentů se slovenskou státní př́islušností vakademickém roce 2011/2012 (stav $k$ 31. 12.)

\begin{tabular}{|c|l|l|r|r|}
\hline \multirow{2}{*}{ Pořadí Název instituce } & \multirow{2}{*}{ Sídlo } & \multicolumn{2}{|c|}{ Studenti ze Slovenska } \\
\cline { 4 - 5 } & & & \multicolumn{1}{|c|}{ počet } & podíl na VŠ * \\
\hline 1. & Masarykova univerzita & Brno & 5812 & 14,6 \\
\hline 2. & Univerzita Karlova & Praha & 3634 & 7,3 \\
\hline 3. & Vysoké učení technické & Brno & 2270 & 10,2 \\
\hline 4. & Vysoká škola ekonomická & Praha & 1878 & 10,0 \\
\hline 5. & Vysoká škola báńská - Technická univerzita & Ostrava & 1008 & 4,7 \\
\hline 6. & České vysoké učení technické & Praha & 971 & 4,3 \\
\hline 7. & Univerzita Palackého & Olomouc & 964 & 4,3 \\
\hline 8. & Univerzita Tomáše Bati & Zlín & 662 & 5,4 \\
\hline 9. & Mendelova univerzita & Brno & 531 & 5,0 \\
\hline 10. & Veterinární a farmaceutická univerzita & Brno & 418 & 13,5 \\
\hline 11. & Slezská univerzita & Opava & 407 & 4,8 \\
\hline 12. & Ostravská univerzita & Ostrava & 255 & 2,5 \\
\hline
\end{tabular}

* podil studentů ze Slovenska na všech studentech dané vysoké školy (\%)

Zdroj: Statistická ročenka školství 2011/2012, MŠMT Praha, 2013; Slotiková (2013)

Podíl slovenských studentů ve veřejných vysokých školách v roce 2011/2012 byl o něco nižší a činil 5,9 \%. O výrazné koncentraci Slováků na českých vysokých školách vypovídá i skutečnost, že tento celorepublikový podíl překročilo pouze 7 škol. Kromě pěti uvedených v tabulce č. 3 se jednalo již 
pouze o umělecké školy: JAMU v Brně (13,5 \% - 95 studentů ze Slovenska) a AMU v Praze (7,6 \% 107 Slováků). Téměř polovina vysokoškolských studentů ze SR studovala na nejprestižnějších českých univerzitách (Univerzita Karlova a Masarykova univerzita). Výhodnější geografická poloha Brna než Prahy vzhledem k území Slovenské republiky bude asi hlavní prííčinou většího počtu slovenských studentů na Masarykově univerzitě. Poměrně malý zájem mají Slováci o studium na univerzitách vzniklých až po roce 1989 a zejména leží-li v západní polovině českého státu. Podíl slovenských studentů na Jihočeské univerzitě v Českých Budějovicích, Západočeské univerzitě v Plzni nebo Univerzitě J. E. Purkyně v Ústí nad Labem se pohybuje pouze okolo 0,5 \%.

Tab. 4: Fakulty veřejných vysokých škol s největším počtem studentů se slovenskou státní př́slušností v akademickém roce 2011/2012 (stav $k$ 31. 12.)

\begin{tabular}{|c|c|c|c|c|}
\hline \multirow{2}{*}{ Pořadí } & \multirow{2}{*}{ Název fakulty/instituce } & \multirow{2}{*}{ Sídlo } & \multicolumn{2}{|c|}{ Studenti ze Slovenska } \\
\hline & & & počet & podíl na VŠ * \\
\hline 1. & Filozofická fakulta MU & Brno & 1198 & 12,5 \\
\hline 2. & Fakulta informatiky MU & Brno & 1031 & 41,4 \\
\hline 3. & Lékařská fakulta MU & Brno & 1028 & 22,3 \\
\hline 4. & Ekonomicko-správní fakulta MU & Brno & 793 & 17,9 \\
\hline 5. & Fakulta mezinárodních vztahů VŠE & Praha & 697 & 14,3 \\
\hline 6. & 1. Lékařská fakulta UK & Praha & 676 & 14,0 \\
\hline 7. & Matematicko-fyzikální fakulta UK & Praha & 639 & 22,1 \\
\hline 8. & Př́rodovědecká fakulta MU & Brno & 624 & 14,5 \\
\hline 9. & Fakulta informačních technologií VUT & Brno & 541 & 22,1 \\
\hline 10. & Fakulta sociálních studií MU & Brno & 530 & 13,4 \\
\hline
\end{tabular}

Zdroj: Statistická ročenka školství 2011/2012, MŠMT Praha, 2013; Slotíková (2013)

Dominance fakult Masarykovy univerzity v žebříčku fakult podle počtu studentů se slovenskou státní př́íslušností je až neuvěřitelná. $Z$ deseti fakult, ve kterých studuje nejméně 500 Slováků je 6 fakult jež jsou součástí Masarykovy univerzity. Podílem Slováků vyniká především Fakulta informatiky MU, ve které se Slováci podílí na studentech fakulty více než 40 procenty. Také podíl studentů se slovenskou státní př́slušností na Fakultě informačních technologií VUT v Brně je velmi vysoký. Analýza dotazníkového šetření realizovaného mezi slovenskými studenty obou výše uvedených fakult prokázala, že rozhodujícím impulzem pro studium na těchto fakultách byla skutečnost, že v Brně jsou lokalizovány střediska zahraničních společnosti s mimořádným zájmem o práci mladých informatiků ve výzkumu a vývoji (IBM, Motorola atd.). Řada slovenských studentů se vyjadřovala o Brně jako o „křemíkovém údolí“ střední a východní Evropy. Část z nich by se chtěla prostřednictvím zahraničních společností dostat později i do vývojových center v západní Evropě nebo USA. Kromě informatiky mají slovenští studenti zájem o studium lékařských fakult, což dokumentují více než desetiprocentní podíly Slováků na všech lékařských fakultách v České republice.

Nebereme-li v potaz studenty soukromých vysokých škol, tak největším střediskem slovenských vysokoškoláků v ČR je Brno (8 974 studentů v akademickém roce 2011/2012). V Brně studuje $45 \%$ slovenských studentů působících na českých veřejných vysokých školách. V Praze je počet studujících Slováků na veřejných školách o něco nižší (6 736 studentů, tj. 33,8 \%). Z uvedeného plyne, že téměř čtyři pětiny ze všech slovenských studentů českých veřejných škol studuje v obou největších městech ČR. Mezi větší koncentrace studentů se slovenskou státní prŕíslušností lze však již zařadit jenom Ostravu (1008 studujících Slováků), Olomouc (964 Slováků) a Zlín (658 Slováků). Potvrzuje to i níže uvedený kartogram obr. 4) 


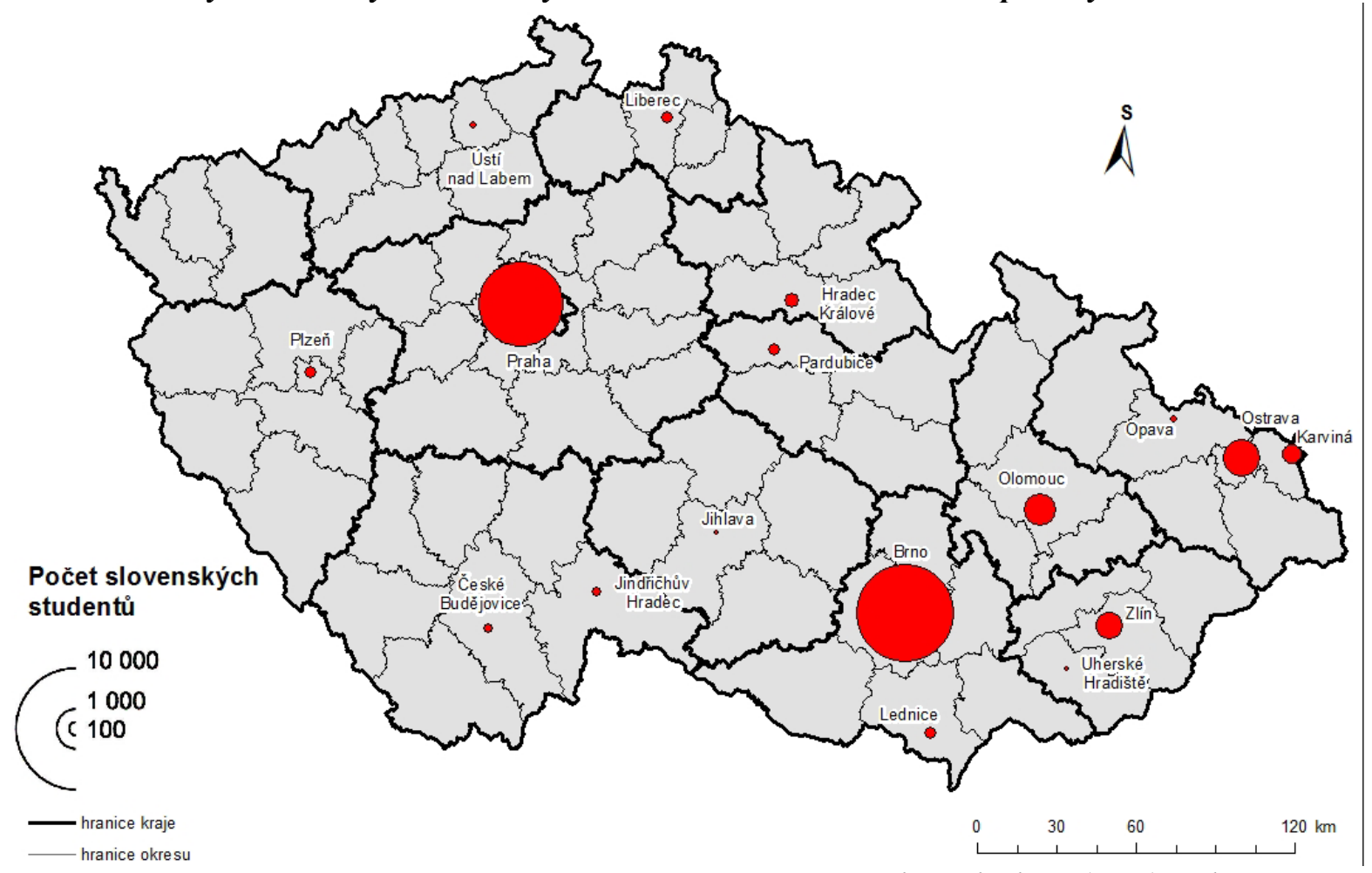

Zdroj: Slotiková (2013) + vlastní výpočty

Oficiální statistické prameny uvádí, že ve školním roce 2011/2012 na soukromých vysokých školách v ČR, především v Praze, působilo 6,8 studentů se slovenskou státní př́slušností. Ve velké většině však tito studenti do Prahy za studiem nedojížděli. Je to př́pad jak Bankovního institutu, tak Univerzity J. A. Komenského nebo i Vysoké školy mezinárodních a veřejných vztahů. Tyto 3 školy vykazovaly spolu 4769 slovenských studentů, tj. $70 \%$ všech studentů se slovenskou státní př́slušností studujících na soukromých vysokých školách v ČR.

Tab. 5: Soukromé vysoké školy s největším počtem studentů se slovenskou státní př́islušností v akademickém roce 2011/2012 (stav $k$ 31. 12.)

\begin{tabular}{|c|l|l|r|r|}
\hline \multirow{2}{*}{ Pořadí } & \multicolumn{2}{|c|}{ Název instituce } & \multirow{2}{*}{ Sídlo } & \multicolumn{2}{c|}{ Studenti ze Slovenska } \\
\cline { 4 - 5 } & & & počet & podíl na VŠ * \\
\hline 1. & Bankovní institut vysoká škola & Praha & 2734 & 58,4 \\
\hline 2. & Univerzita J. A. Komenského & Praha & 1420 & 14,5 \\
\hline 3. & VŠ mezinárodních a veřejných vztahů & Praha & 615 & 53,2 \\
\hline 4. & Evropský polytechnický institut & Kunovice & 351 & 33,2 \\
\hline 5. & Vysoká škola hotelová & Praha & 274 & 13,0 \\
\hline
\end{tabular}

* podil studentů ze Slovenska na všech studentech dané vysoké školy (\%)

Zdroj: Statistická ročenka školství 2011/2012, MŠMT Praha, 2013; Slotíková (2013)

Bankovní institut má lokalizovanou na Slovensku pobočku, která působí v Banské Bystrici pod názvem BIVŠ, zahraniční vysoká škola. Menší část studentů absolvuje studium v samotné Banské Bystrici a větší část v konzultačních střediscích, které jsou umístěny v Galantě, Liptovském Mikuláši a Prešově. Podobně i Univerzita J. A. Komenského působila na Slovensku v Trenčíně, ale po zpřísnění akreditačních podmínek se přesunula na území ČR do nedalekého Starého Hrozenkova, kde univerzita otevřela své konzultační středisko (druhé konzultační stř́edisko je ve Frýdku-Místku). Slovenští studenti mají do školného ve výši 20 tis. Kč za semestr započtenou i dopravu z Trenčína a zpět. Vysoká škola mezinárodních a veřejných vztahů si zrrídila v roce 2008 v Bratislavě Vzdělávací a konzultační institut, ve kterém lze navštěvovat nejen bakalářské, ale i navazující magisterské studium. 
Konkrétně se jedná o denní studium oboru Mezinárodní a diplomatická studia a externí studium oboru Evropská studia a veřejná správa.

Podobně jako Slováci v ČR, mohou studium na slovenských soukromých vysokých školách absolvovat i čeští studenti. Vysoká škola v Sládkovičově působí např́íklad v Brně. Fakultu práva Janka Jesenského na Joštově akademii navštěvovalo v akademickém roce 2011/2012 vice než 600 studentů. Ještě větší počet osob s českým státním občanstvím studoval na Dubnickém technologickém institutu. Jednalo se o externí studium studentů bydlících zejména na moravské straně moravskoslovenského pomezí. Na soukromých vysokých školách na Slovensku působilo v roce 2011/2012 celkem 4242 studentů ze zahraničí, z toho občanů ČR bylo 3861 (v externí formě studia 3 613). Počet cizinců na českých soukromých školách ve stejném roce byl vyšší, a to 9450 . Veřejné vysoké školy na Slovensku navštěvovalo 4977 cizinců (v ČR to bylo 29557 cizinců) a na studenty s českou státní př́slušností připadalo pouze 1016 studentů (434 v denní formě a $582 \mathrm{v}$ externí formě studia). Odhlídneme-li od studia na soukromých vysokých školách a porovnáme počty studentů na veřejných vysokých školách v roce 1992/1993 a v roce 2011/2012 tak počet studentů ze Slovenska do ČR se zvýšil osminásobně, zatímco počet studenti̊ z ČR na Slovensko zůstal zhruba zachován.

\section{Závěr}

Analýza mezistátní dojížd'ky za prací a do vysokých škol mezi Českou a Slovenskou republikou prokázala existující asymetrický model dojížd'ky s výraznou převahou ve směru Slovensko - Česká republika. V nejbližších letech nelze očekávat nějaké výraznější změny obou těchto pohybů. Výzkumy, zejména mezi vysokoškoláky, nehovoří ani tak o rozdílech ve výkonosti ekonomiky obou zemí, ale spíše o rozdílech v kvalitě života. Ta je však podmiňována stavem ekonomiky. K oslabení intenzity pracovní i studijní migrace ze Slovenska do České republiky dojde až patrně v souvislosti s další akcelerací slovenské ekonomiky, která by měla přinést i další vyrovnávání životní úrovně obyvatel obou zemí. Oslabení jednostranných dojížd'kových proudů bude souviset i s měnící se demografickou situací v ČR a SR. Také očekávané zavedení školného na vysokých školách v ČR může mít vliv na snížení počtu studentů ze Slovenska v ČR apod.

\section{Literatura}

[1] DOKOUPIL, J. Diferencující aspekty zkoumání hraničního efektu (na př́íladu česko-bavorského a česko-slovenského pohraničí). In: Balej, M., Jeřábek, M. (eds.) Pohraničí, přihranični spolupráce a euroregiony. Ústí nad Labem: Univerzita J. E. Purkyně, 2002. s. 6977.

[2] HALÁS, M. Cezhraničné väzby, cezhraničná spolupráca: na príklade slovensko-českého pohraničia s dôrazom na jeho slovenskú čast'. Bratislava: Univerzita Komenského, 2005. $152 \mathrm{~s}$.

[3] HALÁS, M., KLADIVO, P. Ekonomický vývoj, väzby a spolupráca medzi Slovenskou a Českou republikou. Regionální studia, 2008, Roč. 2, č. 1, s. 9-15.

[4] HORÁKOVÁ, M. Mezinárodní pracovní migrace v ČR, Bulletin č. 28. VÚPSV, v.v.i., Praha, 2012. $56 \mathrm{~s}$.

[5] JEŘÁBEK, M., DOKOUPIL, J.,. HAVLÍČEK, T. et al. České pohraničí - bariéra nebo prostor zprostředkování? Praha: Academia, 2004. 296 s.

[6] ŘEHÁK, S.. Kontakty se Slovenskem na moravsko-slovenském pomezí: role vzdálenosti hranic. In Borecký, D., Hofmann, E. (eds.) Geografie X. Brno: Masarykova univerzita, 1998. s. $122-126$.

[7] К̌EHÁK, S., DANĚK, P. Změny prostorových interakci vnázorech obyvatel moravsko-slovenského pomezí. Zpráva grantového projektu GA ČR č. 205/95/1184. Brno: Masarykova univerzita, 1997. $35 \mathrm{~s}$.

[8] SLOTÍKOVÁ, Z. Pracovné a študentské aktivity Slovákov v Českej republike. Diplomová práca. Olomouc: Univerzita Palackého v Olomouci, 2013. 117 s.

[9] ŠERÝ, O., HERCIK, J., V. TOUŠEK, V.. Občané Slovenska v České republice téměr̆ dvacet let po rozdělení ČSFR. Brno: Tribun EU, 2012. s. 160-175. 
[10] TOUŠEK, V. Aktuální tendence v zaměstnávání občanů Slovenska v ČR. In Sborník z mezinárodní konference Regionální spolupráce '99. Karviná: Slezská univerzita v Opavě, 1999. s. 307-311.

[11] TOUŠEK, V,. TOMŠÍČKOVÁ, B. Občané Slovenska v České republice sedm let po rozdělení ČSFR (regionálně geografická analýza kontaktů). In Hlaváček, A., Vystoupil, J. (eds.) III. mezinárodni kolokvium o regionálních védách. Sborník referátů. Brno: Masarykova univerzita, 2000. s. 153-165.

[12] Statistické ročenky školství 2002-2011. Ústav pro informace ve vzdělávání, Praha, 2012.

[13] Statistická ročenka školství 2011/2012. MŠMT, Praha, 2013.

[14] Štatistická ročenka 2011/2012 - vysoké školy. Ústav informácií a prognóz školstva. Bratislava, 2013.

[15] Zamestnávanie cudzincov na územi Slovenskej republiky za rok 2011. Ústredie práce, sociálných vecí a rodiny. Bratislava, 2013.

Př́spěvek byl zpracován v rámci řešení projektu „Urbánní a suburbánní kvalita života: geografický pohled“, který je financovaný Grantovou agenturou ČR a v rámci projektu „Projevy globální environmentální změny v krajinné sféře Země“, který je financovaný Masarykovou univerzitou. 